\title{
EFFECT OF MONOMER CONCENTRATION ON PROPERTIES OF POLY (METHYL METHACRYLATE/BUTYL ACRYLATE/VINYL SILICA) EMULSION NANO-COMPOSITE
}

\author{
Mostafa1 $^{1}$, H. Y.; Hussain ${ }^{2}$, A.I.; EL-Masry¹, A.M. and Ahmed Maher ${ }^{3}$ \\ ${ }^{1}$ Depar. of Chemistry, Fac. of Sci., Zagazig Univ., Zagazig, Egypt \\ ${ }^{2}$ Depar. of Polymer and Pigments Chemistry, Nat. Res. Centre, Dokki, Cairo, Egypt \\ ${ }^{3}$ Science and Technology Center of Excellence (STCE), El- Salam City, Cairo, \\ Egypt,Tel: 01067613459, \\ Email: ahmedmaher20102010@yahoo.com
}

\begin{abstract}
Poly (methyl methacrylate-co-butyl acrylate) as shell and vinyl silica nanoparticles as core were prepared by in situ seed emulsion polymerization. The monomer concentration ratio of butyl acrylate $(\mathrm{BuA})$, and methyl methacrylate (MMA) was changed. The ratio of the monomers MMA/BuA were 60/40, 70/30, 40/60 and 30/70 at constant dose of vinyl silica nano-particles 5\% (based on total monomer ratio). The prepared nano emulsions were characterized using thermal analyses, HRTEM, FTIR and Zeta potential. The results have shown that monomer concentration ratio had a significant influence on glass transition temperature $(\mathrm{Tg})$. Thermo gravimetric analysis showed that the systems with higher BuA fraction had better thermal stability than systems with higher (MMA) fraction.
\end{abstract}

Keywords: methyl methacrylate, butyl acrylate, vinyl silica, core-shell, monomer concentration

\section{INTRODUCTION}

Incorporation of nano-scale inorganic materials to organic polymers was increasing potential for future applications due to the advantageous properties of the organic polymer species such as elasticity, process ability with inorganic fillers providing high thermal stability and reinforcement (Paul, D and Robeson, L., 2008; Essawy, H. et al., 2016). It has been reported that small percentage $(5 \% \mathrm{wt})$ of nanoparticles embedded in a polymer matrix can exhibit significant improvement in material properties (Romo-Uribe, A. et al., 2016). The properties of nano-composites are greatly influenced by both the degree of dispersion of nano-particles in the base polymers and the interfacial adhesion between the inorganic and organic components (Chen, C. et al., 2014). In 
suspension, dispersion, emulsion and mini-emulsion polymerization the nanocomposites are formed by carrying out polymerization in the presence of inorganic particles which seem the ideal route to achieve good dispersion in the base polymers (Chern, C.S. et al., 2008; Ahmed A.E.S.I., et al., 2016). In situ emulsion polymerization, as one of the most often used methods, can produce not only organic-inorganic hybrids but also environmental friendly copolymers (Qi, D.M. et al., 2006). Results of previous research (Daniel, B. and Wolfgang, B., 2015) showed that with in situ polymerization, in relation to the other preparation processes, best distribution and dispersion of the filler in polymer matrix was achieved.

Nano-silica were attractive nano-reinforced of polymers due to enhancement of physical properties, it has been reported that $\mathrm{SiO}_{2}$ nanoparticles increased macro-hardness, micro-hardness, abrasion resistance, scratch resistance and Young's modulus (Qi, D., et al., 2015), Thus Nano-silica is the most widely used inorganic material in emulsion polymerization.

Organic or inorganic systems with various particle morphologies can be prepared with different procedures of in situ emulsion polymerization. In recent years, particular interest was directed in the development of processes to gain core-shell morphology (Liu, H. et al., 2008) where silica was a core and polymer was a shell. It was assumed that with such morphology the best distribution of the inorganic component in emulsions and films prepared from emulsions can be achieved.

Encapsulation was regarded as being of major importance since it offered interesting potential applications in different fields. Thus, encapsulation of nano-silica with polymer can improve the compatibility of nano-silica in the polymer matrix resulting in an improvement of filler dispersion and performance of the polymer composite (Shin, K. et al., 2010). Encapsulation of silica nano-filler with polymer, i.e. encapsulation efficiency depends on: (a) nature of inorganic particle (silane grafting density), concentration and size of silica nano-filler, (b) use of high hydrophilic monomers, (c) nature and concentration of monomer, initiator, and emulsifier in polymerization and (d) degree of dispersion of nano-particles in the base polymers and the interfacial adhesion between the inorganic and organic components (Chen, C., et al., 2014; Wen, X. et al., 2008). Depending on the above factors various morphologies such as core-shell, daisy like, petal like, raspberry like, and multilayered morphology were obtained (Bourgeat-Lami, E., 2004).

\section{Materials}

\section{MATERIALS AND METHODS}

Triethoxyvinylsilane (TEVS), ammonium hydroxides $\left(\mathrm{NH}_{4} \mathrm{OH}, 35 \%\right)$ and ethanol (analytical reagent) were purchased from Sigma-Aldrich. methyl methacrylate (MMA), n-butyl acrylate (BuA), acrylic acid (AA) (99\%), 
potassium peroxydisulfate (KPS), nonyl phenol polyethylene glycol ether (NP30), sodium acetate anhydrous, sodium dodecylbenzene-sulfonate (SDBS) and sodium dodecyl sulfate (SDS) were supplied by Across Chemical. All ingredients were used as received without further purification. Doubly distilled water was used throughout the experiments.

\section{In situ preparation of nano-composite emulsions}

Vinyl silica spheres were prepared by sol-gel technique in an aqueous solution as reported in literature (Ahmed, A.E.S.I., et al., 2015A; Mostafa, H.Y., et al., 2015), scheme (1). The emulsion polymerization was carried out in a $500 \mathrm{~mL}$ four neck flask which was equipped with an inlet for nitrogen gas, reflux condenser, thermocouple, Teflon-steel mechanical stirrer and feeding inlets through two steps.

\section{A. Core stage}

Calculated amount of vinyl silica in grams and NP-30 were dispersed in (33 g) water with $10 \%$ of pre-emulsified mixture of monomers containing: BuA, MMA, SDS and via gentle stirring for $15 \mathrm{~min}$ followed by sonication ( Hielscher, UP200S) in ice bath for 20 min. The mixture was poured into a reactor containing buffer solution under stirring $(80 \mathrm{rpm})$. Calculated amount of potassium persulphate (KPS) solution ( $0.5 \mathrm{~g}$ dissolved in $10 \mathrm{~g} \mathrm{H}_{2} \mathrm{O}$ ) was drop-wise added into the reactor and left for $30 \mathrm{~min}$ to produce the core stage.

\section{B. Shell stage}

The remaining pre-emulsified mixture containing ( $3 \mathrm{~g}$ ) acrylic acid was charged using a dual syringe pump within $180 \mathrm{~min}$ to obtain methyl methacrylate/butyl acrylate/ vinyl silica composite emulsion as shown in table (1). The mixture was cooled to $40^{\circ} \mathrm{C}$ and $\mathrm{pH}$ was adjusted to be 8 as shown in scheme (2).

\section{Characterization}

The coagulum was obtained gravimetrically (Zhang, F. et al., 2004). Viscosity of the latex was determined according to ASTM D 2196 using digital viscometer (Brookfield viscometer DV-I Prime). Solid content was determined as recorded in ASTM D 2369. Fourier transform infrared (FTIR) spectra of nano-composite films were measured in the range $4000-500 \mathrm{~cm}^{-1}$ at room temperature using (Thermo Nicolet Avatar 370) spectrometer. The glass transition of the films was further studied by Differential scanning calorimetry DSC in a (TA Instruments Q2000). The thermal history of the samples was erased by heating from 20 to $100^{\circ} \mathrm{C}$ at heating rate $10^{\circ} \mathrm{C} \mathrm{min}^{-1}$ and nitrogen purge flow of $50 \mathrm{ml} \mathrm{min}^{-1}$. The thermal stabilities of the films were evaluated by TGA, using a (TA Instruments Q500 equipment thermo-gravimetric analyzer). Samples were heated at nitrogen purge flow $50 \mathrm{ml} / \mathrm{min}^{-1}$ at $25-500^{\circ} \mathrm{C}$ at a heating rate of $10^{\circ} \mathrm{C} \mathrm{min}{ }^{-1}$. High Resolution Transmission electron 
microscopy (HR-TEM) was used to investigate the morphology of structural hybrid emulsion latex particles with FEI TECHNAI G20Stwin transmission electron microscope at an acceleration voltage of $200 \mathrm{kV}$. A Malvern Zetasizer instrument 103 was used to measure $\zeta$ values of the nanocomposite emulsion latex at $\mathrm{pH} 8.5$ and temperature $25^{\circ} \mathrm{C}$.

\section{RESULT AND DISCUSSIONS \\ Solid content, coagulum content and viscosity}

In this paper, Vinyl silica nanoparticles were prepared by sol-gel technique as shown in scheme (1) and in situ encapsulated with poly (methyl methacrylateco-butyl acrylate) emulsion with different monomer concentration ratios [butyl acrylate (BuA) and methyl methacrylate (MMA)] in presence of nonionic emulsifier to obtain good dispersability of nano-silica in polymer matrix. Thermal, optical, and morphological properties of nano-composite films were studied.

It is clear from table (2) that the solid content and viscosity of emulsion samples containing high concentration of (MMA) is more than emulsion samples containing high concentration of (BuA). On the other hand, the coagulum of emulsions of high concentration of (MMA) were lower than that of high concentration of $(\mathrm{BuA})$ samples. The conglutination of the vinyl silica was due to the adhesive action and entanglements of $(\mathrm{BuA})$ chains increasing the coagulum and decreasing the solid content (Zheng, j. et al. 2009; Fielding, L.A. et al., 2011). Thus, the solid content decreased and the coagulum content increased.

\section{FTIR spectra of nano-composite films}

The spectra of poly(MMA/BuA)/vinyl silica for different monomer concentration ratio were shown in figure (1). It was showing a number of characteristic spectral bands; peaks at 2956 and $2874 \mathrm{~cm}^{-1}$ can be attributed to the stretching vibration of methyl and methylene groups. The strong adsorption peaks at 1732 and $1166 \mathrm{~cm}^{-1}$ were corresponding to carbonyl $(\mathrm{C}=\mathrm{O})$ and asymmetric $\mathrm{C}-\mathrm{O}-\mathrm{C}$ stretching vibrations (Mahdavian, A.R. et al., 2007; Chang, G. et al., 2013). The beak at $1458 \mathrm{~cm}^{-1}$ is associated with the characteristic vibration of $\left(\mathrm{CH}_{3}\right)$ group. FTIR spectra clearly display typical absorption peaks of $\mathrm{Si}-\mathrm{O}-\mathrm{Si}$ which appears at 1100 and $470 \mathrm{~cm}^{-1}$ (Zhou, X. et al., 2013). FTIR spectra of $C$ and $D$ films showed the same peaks of A and B films, clearly displays typical peaks at $2874 \mathrm{~cm}^{-1}$ of methylene groups with higher intensity (Fielding, L.A. et al., 2011).

\section{Thermal stability of nano-composite films}

Figure (2) and table (3) represent TGA curves and data for systems. It was clear that residue percent at $500^{\circ} \mathrm{C}$ increased by increasing butyl acrylate fractions. 
The systems with higher concentration of butyl acrylate fractions were more stable than systems with methyl methacrylate fractions in the presence of vinyl silica, this was due to the blocking action of butyl acrylate sequences (Leskovac, M. et al., 1999). This behavior was similar to poly (methyl methacrylate-co-butyl acrylate)/pyrogenic silica system (Buhin, Z. et al., 2013).

\section{Glass transition of nano-composite films}

Figure (3) represents the glass transition of poly(MMA/BuA) with different monomer concentration (containing 5\% vinyl silica). It was clear that increasing the concentration of hard monomer (MMA) in the matrix leads to an increase in the glass transition. On the other hand, a dramatic reduction in glass transition was recorded by increasing the soft monomer $(\mathrm{BuA})$ (Ahmed A.E.S.I. et al., 2015B).

\section{Morphological analysis}

The normal core-shell structure emulsion particles could be obtained with core formed from hydrophobic monomers and shell formed from hydrophilic ones. On the contrary, the hydrophobic copolymer as shell part would migrate into the emulsion particles during polymerization to form special morphology, such as strawberry-, snowman- and island-like (Ma, J. et al., 2013).

Representative TEM images were shown in figure (4) (a- d). As more (BuA) co-monomer was introduced, the nano-composite particles begin to coalesce on the TEM grid. This is expected, as the lower copolymer $T_{\mathrm{g}}$ promotes film formation during drying (Fielding, L.A. et al., 2011). Figure (4) (c, d) showed that the total particle size of vinyl silica/methyl methacrylate/butyl acrylate copolymer emulsions with $5 \%$ of vinyl silica increased gradually as $(\mathrm{BuA})$ content increased and were found to be $719,735 \mathrm{~nm}$. However, for high content of (MMA) in figure (4) $(a, b)$ the total particle size decreases as (MMA) content increased and were found to be $695,674 \mathrm{~nm}$.

\section{Zeta potential}

Table (4) and figure (5), respectively, showed that for all the samples tested of different monomer concentration of poly $(\mathrm{MMA} / \mathrm{BuA})$ (containing 5\% of vinyl silica) emulsions (A-D), the $\zeta$ potential values were lower than $-35 \mathrm{mV}$, indicating that the electrostatic interaction was enough to stabilize the composite latexes (Ramos-Fernández, J. et al., 2011). It was clear from table (4) that nano-composite (D) had higher stability than the rest of samples and vinyl silica shows a good particle size distribution through the latex of (A-D). 


\section{CONCLUSIONS AND RESULTS}

The effect of monomer concentration ratio on emulsion morphology and thermal properties of the poly (MMA/BuA)/vinyl silica films at constant vinyl silica content were investigated. Results of DSC analysis showed that monomer concentration ratio has significant influence on copolymer glass transition temperature. BuA-rich nano-composite films showed more thermal stability than MMA-rich films. Vinyl silica showed a good particle size distribution through the latex of all samples. BuA-rich nano-composite emulsions showed more stability than MMA-rich one.

\section{REFRENCES}

Ahmed, A.E.S.I.; Hussain, A.; El-Masry, A and Saleh, A. (2015a). Effect of changing monomer concentration ratio of styrene/butyl acrylate on the behavior of nano organo-silica in poly (Styrene-co-Butyl acrylate) emulsion core-shell. ARPN Journal of Engineering and Applied Sciences, 10: 6127- 6134.

Ahmed, A.E.S.I.; Hussain, A.; El-Masry, A and Saleh, A. (2015b) Thermomechanical Properties of Styrene-butyl acrylate/Organo-silica nanocomposite Films prepared by Seed Emulsion Polymerization, Polymer Composites, Wiley Online Library (wileyonlinelibrary.com), DOI 10.1002/pc.23560.

Ahmed, A.E.S.I.; Hussain, A.; El-Masry, A and Saleh, A. (2016). Poly (styrene-co-butyl acrylate)/organo-silica core-shell and ethylene vinyl acetate nanocomposites. Polymer Composites, DOI 10.1002/pc.24061.

Bourgeat-Lami, E. (2004). Organic/inorganic nano-composite colloids. Encyclopedia of nanoscience and nanotechnology, 8: 305-332.

Buhin, Z.; Blagojević, S.L and Leskovac, M. (2013). In situ emulsion polymerization and characterization of poly (butyl acrylate-co-methyl methacrylate)/silica nanosystems. Polymer Engineering \& Science, 53: 2292-2298.

Chang, G.; He, L.; Zheng, W.; Pan, A.; Liu, J.; Li, Y and Cao, R. (2013). Well-defined inorganic/organic nanocomposite by nano silica core-poly (methyl methacrylate/butylacrylate/trifluoroethyl methacrylate) shell. Journal of colloid and interface science, 396: 129-137.

Chen, C.; Ding, Z.; Tan, Q.; Qi, H and He, Y. (2014). Preparation of nano $\alpha$-alumina powder and wear resistance of nanoparticles reinforced composite coating. Powder Technology, 257: 83-87.

Chern, C.S. (2008). Principles and applications of emulsion polymerization: John Wiley \& Sons, 175-186.

Daniel, B and Wolfgang, B. (2015). Synthesis of polyamide-imide- 
montmorillonite-nanocomposites via new approach of in situ polymerization and solvent casting. Progress in Organic Coatings, 82: 26-32.

Essawy, H.; Moustafa, A.; Abd El-Aziz, M and Hussein, A. (2016). Pickering Emulsion Polymerization of Styrene Using Nano-SiO2 and Subsequent Use of the Produced Core-Shell Structures as Fillers for Ethylene Vinyl Acetate Copolymer and Polypropylene. Polymer-Plastics Technology and Engineering. (just-accepted).

Fielding, L.A.; Tonnar, J and Armes, S.P. (2011). All-acrylic film-forming colloidal polymer/silica nanocomposite particles prepared by aqueous emulsion polymerization. Langmuir, 27: 11129-11144.

Leskovac, M.; Kovacevic, V.; Fle, D and Hace, D. (1999). Thermal stability of poly (methyl methacrylate-co-butyl acrylate) and poly (styrene-cobutyl acrylate) polymers. Polymer Engineering \& Science, 39: 600-608.

Liu, H.; Ye, H.; Lin, T and Zhou, T. (2008). Synthesis and characterization of PMMA/Al2O3 composite particles by in situ emulsion polymerization. Particuology, 6: 207-213.

Ma, J.; Liu, Y.; Bao, Y.; Liu, J and Zhang, J. (2013). Research advances in polymer emulsion based on "core-shell" structure particle design. Advances in colloid and interface science, 197: 118-131.

Mahdavian, A.R.; Ashjari, M and Makoo, A.B. (2007). Preparation of poly (styrene-methyl methacrylate)/SiO2 composite nanoparticles via emulsion polymerization. An investigation into the compatiblization. European polymer journal, 43, 336-344.

Mostafa, H.Y; Hussain, A.; El-Masry, A and Maher, A. (2016). Novel core-shell of polymethyl methacrylate/butyl acrylate/vinyl silica nanocomposite Particles via seed emulsion polymerization. PolymerPlastics Technology and Engineering (just-accepted).

Paul, D and Robeson, L. (2008). Polymer nanotechnology: nanocomposites. Polymer, 49(15): 3187-204.

Qi, D.; Liu, C.; Chen, Z.; Dong, G and Cao, Z. (2015). In situ emulsion copolymerization of methyl methacrylate and butyl acrylate in the presence of $\mathrm{SiO} 2$ with various surface coupling densities. Colloid and Polymer Science, 293: 463-471.

Qi, D.M.; Bao, Y.Z.; Weng, Z.X and Huang, Z. (2006). M. Preparation of acrylate polymer/silica nanocomposite particles with high silica encapsulation efficiency via miniemulsion polymerization. Polymer, 47(13): 4622-9.

Ramos-Fernández, J.; Guillem, C.; Lopez-Buendía, A.; Paulis, $M$ and Asua, J. (2011). Synthesis of poly-(BA-co-MMA) latexes filled with $\mathrm{SiO} 2$ for coating in construction applications. Progress in Organic Coatings, 72: 438-442. 
Romo-Uribe, A.; Arcos-Casarrubias, J.A.; Hernandez-Vargas, M.L.; Reyes-Mayer, A.; Aguilar-Franco, $M$ and Bagdhachi, J. (2016). Acrylate hybrid nanocomposite coatings based on $\mathrm{SiO} 2$ nanoparticles by in-situ batch emulsion polymerization. Progress in Organic Coatings, 97: 288-300.

Shin, K.; Kim, J.J and Suh, K.D. (2010). A facile process for generating monolithic-structured nano-silica/polystyrene multi-core/shell microspheres by a seeded sol-gel process method. Journal of colloid and interface science, 350(2):581-585.

Wen, X.; Li, M.; Pi, P.; Chen, J and Yang, Z. (2008). Study of the physicochemical properties of silica powder and the stability of organicinorganic hybrid emulsion in the presence of ethanol. Colloids and Surfaces A: Physicochemical and Engineering Aspects, 327: 103-110.

Zhang, F.; Wang, Y and Chai, C. (2004). Preparation of styrene-acrylic emulsion by using nano-SiO2 as seeds. Polymer international, 53: 13531359.

Zheng, J.; Zhou, X.; Ying, J.; Xie, $X$ and Mai, Y. (2009). Enhanced mechanical properties of polypropylene/silica nanocomposites with surface modification of nano-silica via in situ copolymerization of methyl methacrylate and butyl acrylate. Chinese Journal of Polymer Science, 27: 685-694.

Zhou, X.; Shao, H and Liu, H. (2013). Preparation and characterization of film-forming raspberry-like polymer/silica nanocomposites via soap-free emulsion polymerization and the sol-gel process. Colloid and Polymer Science, 291: 1181-1190. 
Table (1). Formulation of the nano-composite emulsion polymers.

\begin{tabular}{|c|c|c|c|c|}
\hline \multirow{2}{*}{ Ingredients } & \multicolumn{4}{|c|}{ Emulsion } \\
\cline { 2 - 5 } & A & B & C & D \\
\hline methyl methacrylate & 60 & 70 & 40 & 30 \\
\hline Butyl acrylate & 40 & 30 & 60 & 70 \\
\hline Vinyl silica & 5 & 5 & 5 & 5 \\
\hline
\end{tabular}

Table (2). Solid content, coagulum content and viscosity.

\begin{tabular}{|c|c|c|c|c|}
\hline \multirow{2}{*}{$\begin{array}{c}\text { Sample } \\
\text { Ingredients }\end{array}$} & \multicolumn{4}{|c|}{ Emulsion } \\
\cline { 2 - 5 } & $\mathbf{A}$ & $\mathbf{B}$ & $\mathbf{C}$ & $\mathbf{D}$ \\
\hline Solid content \% & 52.6 & 53.7 & 51.9 & 50.1 \\
\hline Coagulum content \% & 2.35 & 2.23 & 2.45 & 2.62 \\
\hline Viscosity (CPs) & 12846 & 13351 & 7758 & 9588 \\
\hline
\end{tabular}

Table (3). Thermal stability data derived from TGA curves of mass ratio.

\begin{tabular}{|c|c|c|c|c|c|}
\hline Sample & $\begin{array}{c}\mathbf{T}_{\mathbf{5}} \\
\left({ }^{\circ} \mathbf{C}\right)\end{array}$ & $\begin{array}{c}\mathbf{T}_{\mathbf{5 0}} \\
\left({ }^{\circ} \mathbf{C}\right)\end{array}$ & $\begin{array}{c}\text { Temp at the } \\
\text { largest Decomp } \\
\text { rate, } \\
{ }^{\circ} \mathbf{C}\end{array}$ & $\begin{array}{c}\text { Mass fraction } \\
\text { of total weight } \\
\text { loss }(\boldsymbol{\%}) \\
\text { at } \mathbf{5 0 0}\end{array}$ & $\begin{array}{c}{ }^{\circ} \mathbf{C} \\
\text { Residue } \\
(\mathbf{\%}) \\
\text { at } \mathbf{5 0 0}\end{array}$ \\
\hline A & 290.03 & 379.76 & 389.69 & 95.56 & 4.4 \\
\hline B & 308.08 & 385.51 & 394.06 & 96.74 & 3.2 \\
\hline C & 284.32 & 394.58 & 400.33 & 94.32 & 5.6 \\
\hline D & 343.24 & 396.85 & 401.10 & 94.09 & 5.9 \\
\hline
\end{tabular}

Table (4). Zeta potential results of changing the monomer concentration effect.

\begin{tabular}{|c|c|}
\hline Emulsion & Zeta potential \\
\hline A & -47.8 \\
\hline B & -49.2 \\
\hline C & -47.8 \\
\hline D & -50.8 \\
\hline
\end{tabular}




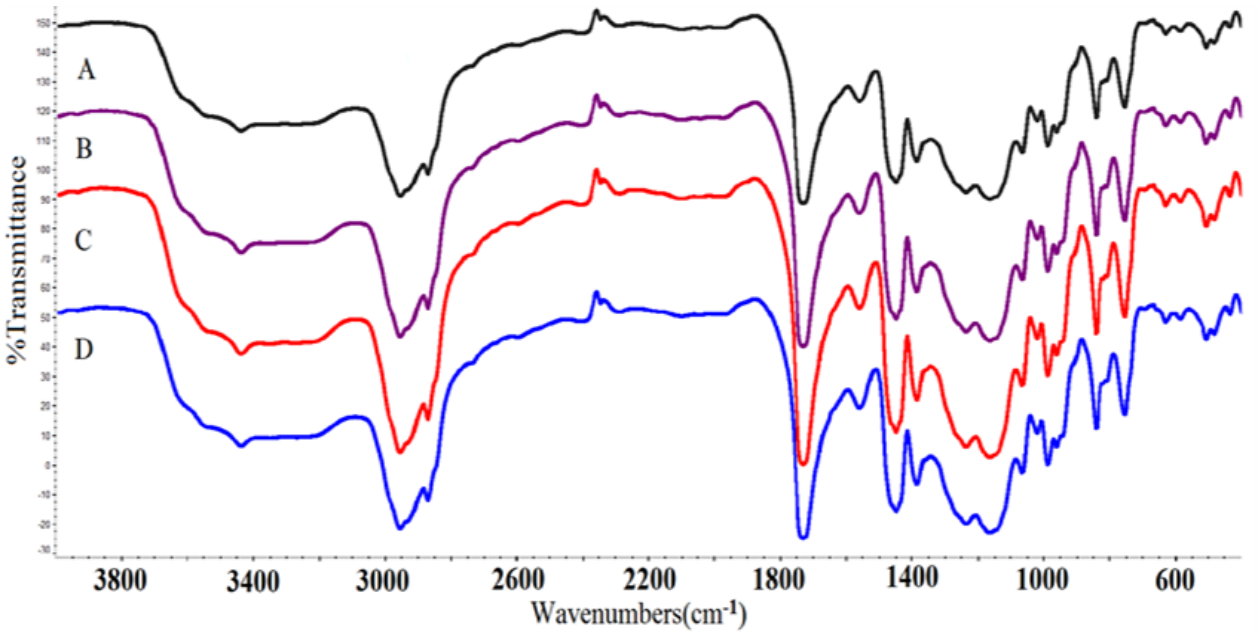

Figure (1). FTIR spectra of nano-composite films
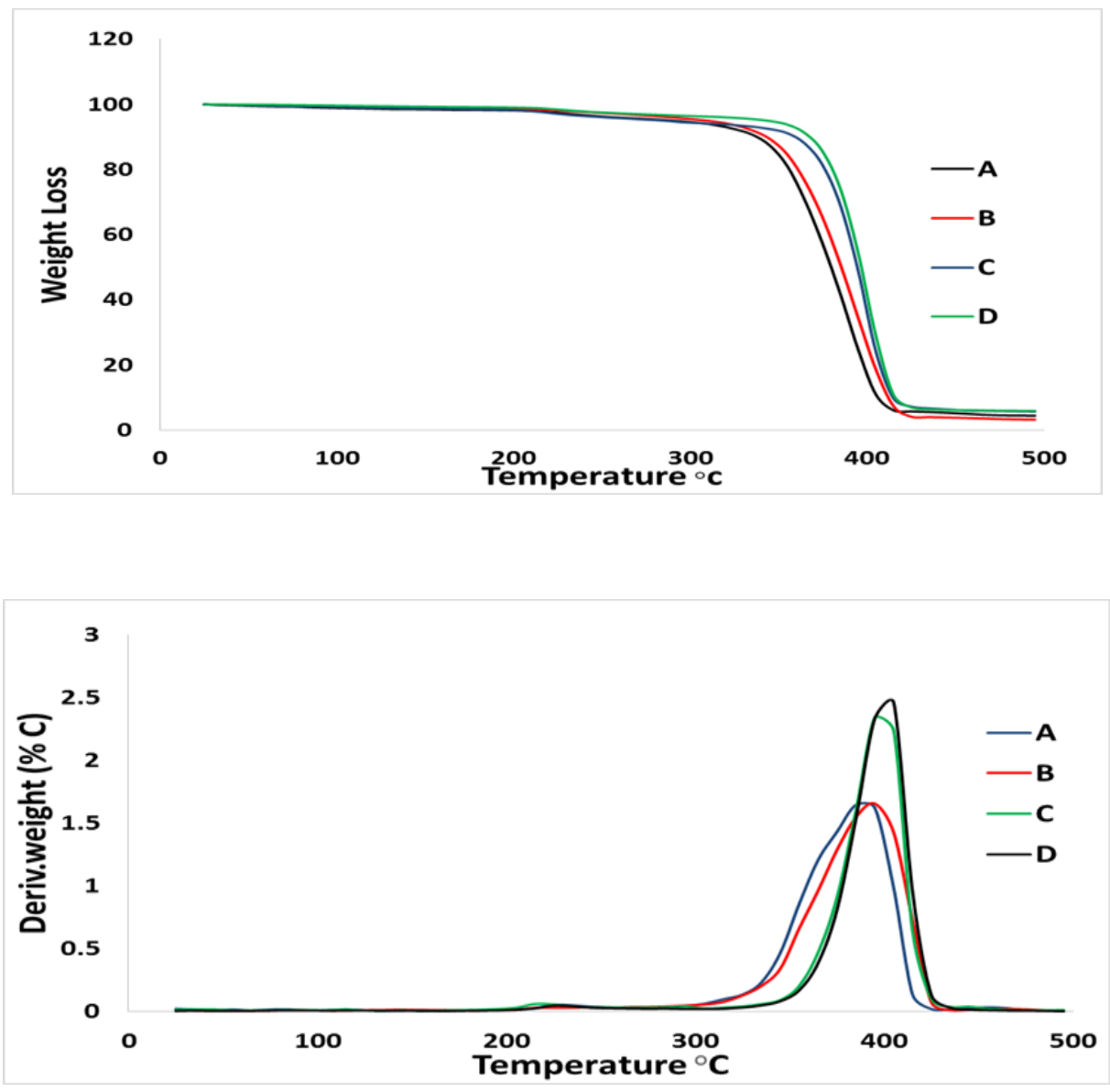

Figure (2) TGA thermograms of (a) weight loss and (b) DTG 


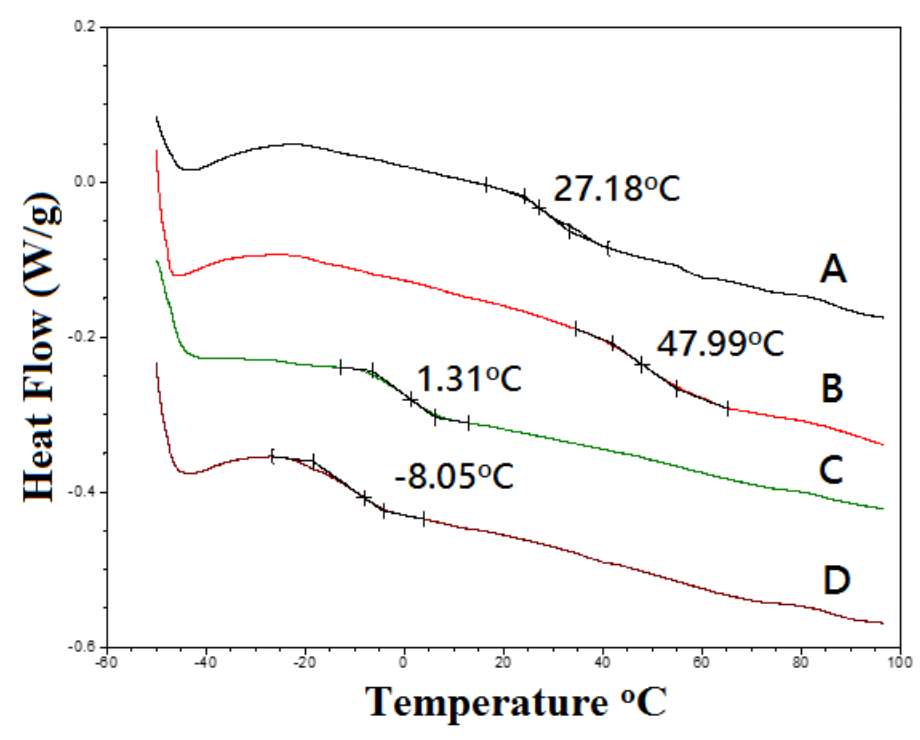

Figure (3) DSC thermograms of nano-composite films
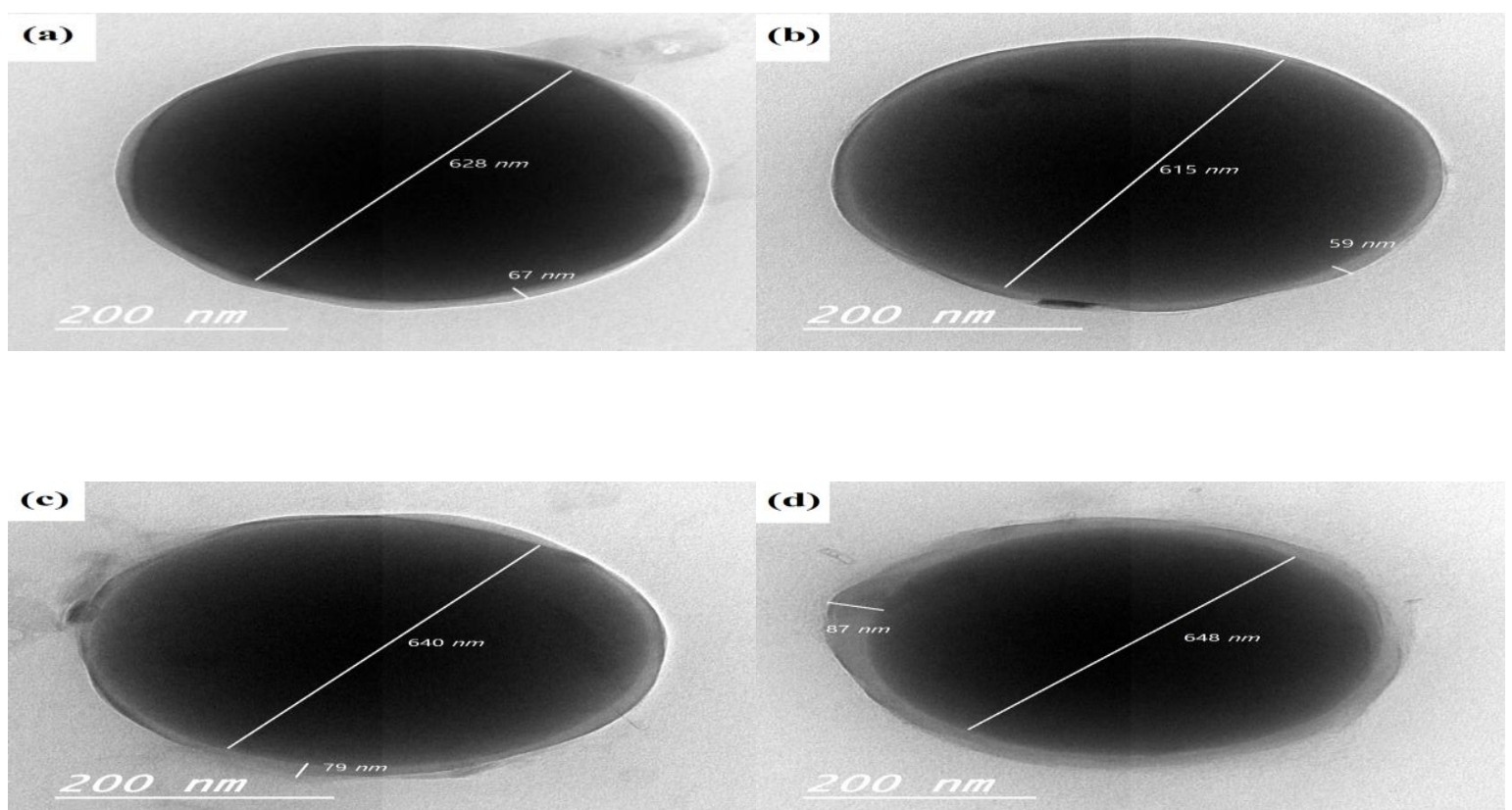

Figure (4) TEM of (a) sample A, (b) sample B, (c) sample C and (d) sample D. 

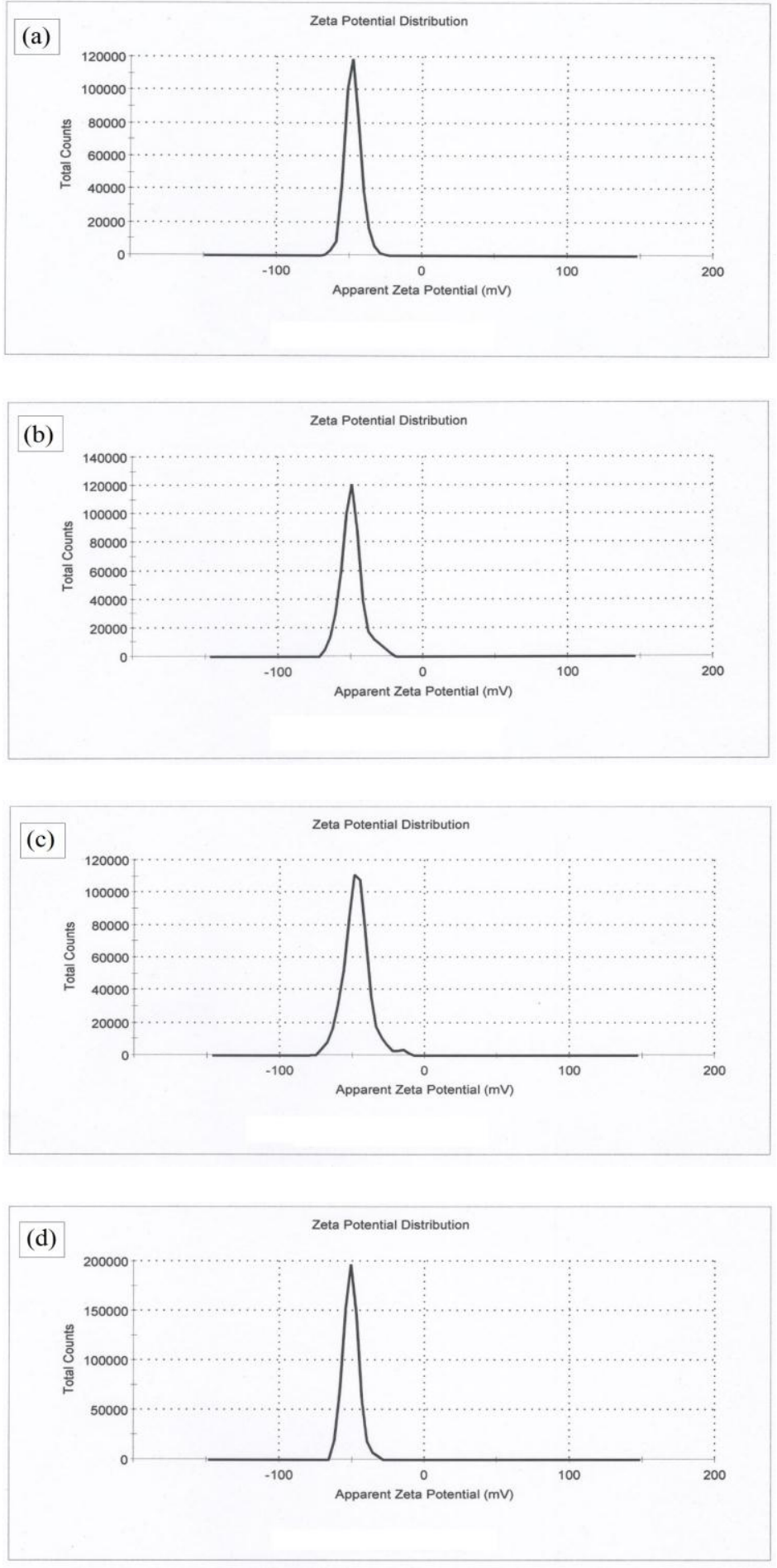

Figure (5) Zeta potential of (a) sample A, (b) sample B, (c) sample C and (d) sample D. 


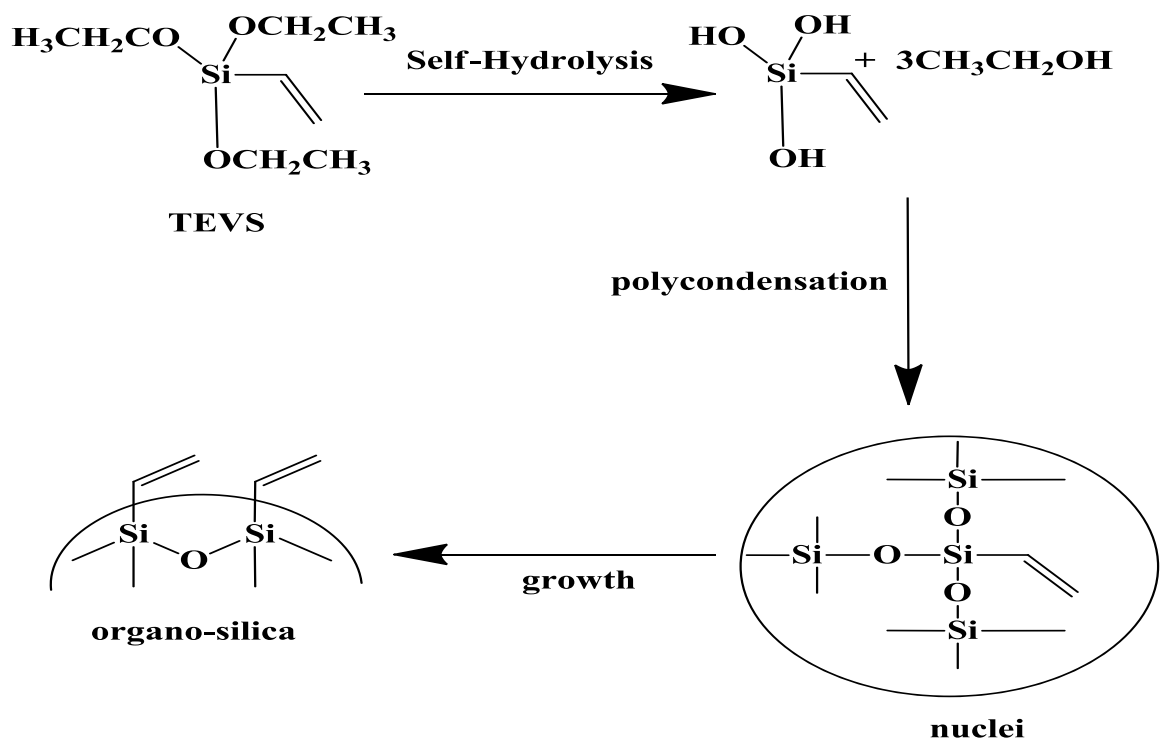

Scheme (1) Formation mechanism of vinyl silica spheres.

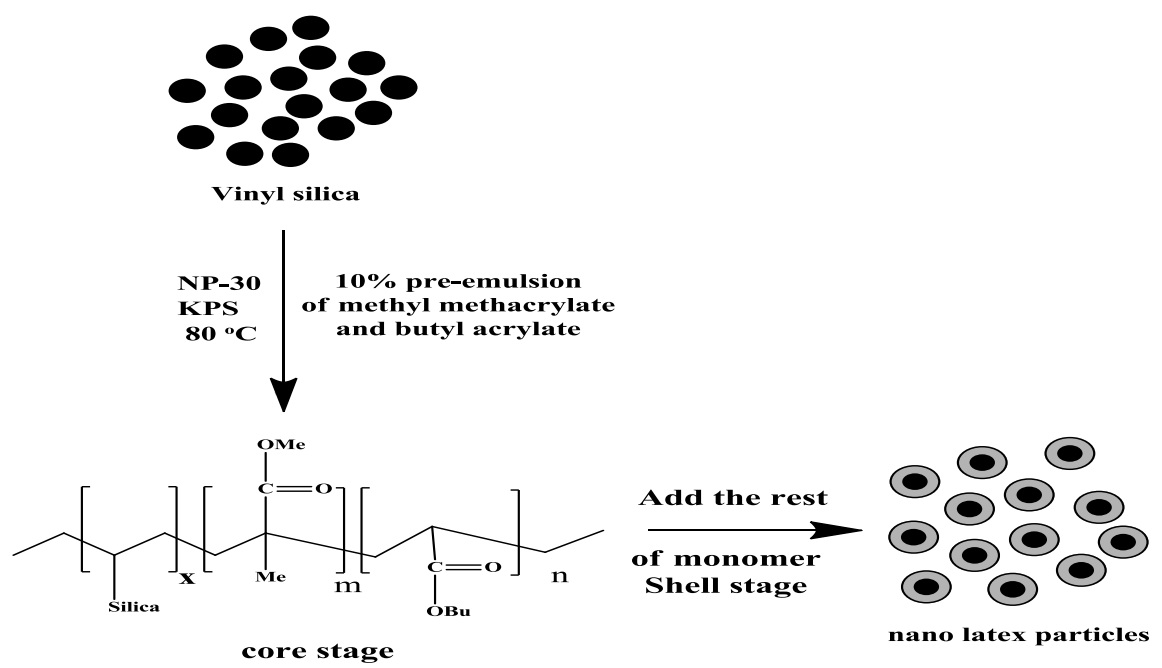

Scheme (2) Preparation of vinyl silica/methyl methacrylate/butyl acrylate copolymer. 


\section{تأثير تركيز المونومر على خواص مستحلب نانومترى من

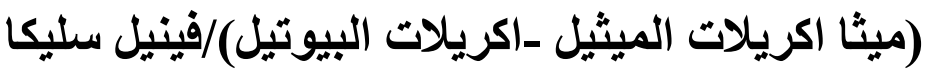

ا.م/ حامد يوسف يوسف مصطفي' ، ا.د/ احمد اسماعيل حسين ، ا.د/ احمد مؤمن المصري '، احمد ماهر”

ا قسم الكيمياء، كلية العلوم، جامعة الزقازيق، الزقازيق، جمهورية مصر العربية.

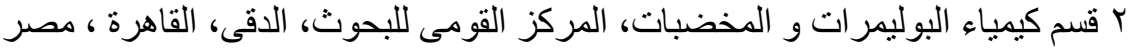

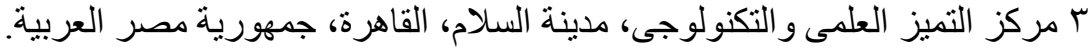

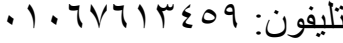

فى هذه الدر اسة تم تحضير بوليمر (ميثا أكريلات الميثيل ـاكريلات البيوتيل)/فينيل سليكا بإستخدام طريقة البلمرة الاستحلابية. تم در اسة تأثثر تغيير تركيز مونومر ميثا أكريلات الميثيل بالنسبة لاكريلات

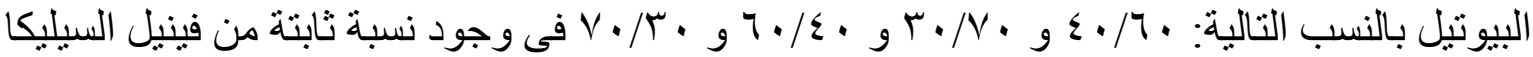
النانوية (0\%) من كمية المونومر. تم تقييم النتائج باستخدام التحليل الطيفى (الاشعة تحت الحمراء و الميكرسكوب الالكترونى النافذ) و اثبتت التحاليل المختلفة التى تم اجرائها على ناتج التفاعل التالى: تغيير نسبة المونومر له تأثير قوى على درجة التزجج. الثبات الحرارى للعينات المحتوية على التركيز المرتفع من مونومر اكريلات البيوتيل اكبر من العينات ذات التركيز المرتفع من مونومر ميثا أكريلات الميثيل. عينات البوليمر المحتوية على نسب أعلى من اكريلات البيوتيل أكثر ثباتا من عينات البوليمر المحتوية على نسب ميثا أكريلات الميثيل. 